\title{
'Out of Place', 'Knowing One's Place': space, power and the exclusion of disabled people
}

\section{ROB KITCHIN}

School of Geosciences, Queen's University of Belfast, BT7 1NN, UK

\begin{abstract}
Disabled people are marginalised and excluded from 'mainstream' society. In general, our understanding of the processes of exclusion is grounded in time and history. In this paper, it is argued that space, as well as time, is instrumental in reproducing and sustaining disablist practices. Disability has distinct spatialities that work to exclude and oppress disabled people. Spaces are currently organised to keep disabled people 'in their place' and 'written' to convey to disabled people that they are 'out of place'. Furthermore, social relations currently work to spatially isolate and marginalise disabled people and their carers. Disability is spatially, as well as socially, constructed. It is contended that an understanding of society's reaction to, and the experiences of, disability should be framed within an approach that combines a spatialised political economy with social constructivism. Unlike neo-Marxist approaches this approach is centred on notions of power rather than capital. Using this approach, the spatialities of disability are explored.
\end{abstract}

\section{Space, Power and Exclusion}

It is now generally recognised that disabled people are marginalised and excluded from 'mainstream' society. Disabled people represent one of the poorest groups in Western society. Apart from being excluded and marginalised from the workplace disabled people are often segregated within schooling, unable to find suitable housing, and have restricted access to public transport (Oliver, 1996). In general, our understanding of the processes of exclusion is grounded in time and history. For example, adopting a Marxist (materialist) approach, Michael Oliver (1990) has sought to demonstrate that disabled people are socially excluded because they are deemed unproductive and so hinder the progress of capital accumulation. He suggests that the role of disabled people within society radically altered with the onset of the industrial revolution and the shift from the land to the factory. Disabled people unable to be as productive as their able-bodied counterparts were excluded or marginalised from the production process. He argues that exclusionary processes were reinforced by the State through ideologies of individualism (disability is an individual rather than societal problem) and medicalisation (the need for disability 
to be treated). As such, Oliver (1990) views disability as a social construct used to maintain capitalist concerns, with the experiences of disability determined by the economy (Oliver, 1996). A Marxist or political economy approach is not, however, the only way to try and explain the bases of social exclusion.

Theories from psychoanalysis or social constructivism could also be used to illustrate why disabled people are oppressed. For example, psychoanalysts suggest that the fear or repulsion for Other is deeply embedded with in human nature from birth (Sibley, 1995). There is a natural (Freud) or socialised (Butler, Haraway) tendency for us to categorise objects into 'good' or 'bad' as a basic condition for survival. Drawing on theories of the relationship between self and the social and material world, psychoanalysts suggest that boundaries are defined and formed to protect the self, but also define the self (see Sibley, 1995). These boundaries are then moulded and given shape through our life experiences and learned cultural representations. The construction of Other, to be suspicious of perceived differences, then, is a deep-seated method of self-protection leading to the grouping of like-minded individuals. Groupings are formed to provide social networks of similar people, protecting members from the threat of Others. Social constructivists, building upon psychoanalytical thought, would argue that these groupings are constructions of the subjective self: we are all unique and different and thus categories such as disability, gender and race are really misnomers. They suggest that categories although portrayed as inevitable or essential (they do exist), are really just fabrications of cultural practice (Shurmer-Smith and Hannan, 1994). In other words, they suggest that rather than being born with a predisposition to recognise and categorise Other, we learn to categorise through cultural practice; rather than being taught to accept difference we are taught by our elders to categorise into sameness and to protect the sanctity of this sameness. Other, then, is a socially-constructed category of oppression that is not necessary related to capital concerns as suggested by Oliver (1990).

In this paper, two inter-related arguments are forwarded. First, the role of space in reproducing and maintaining the processes of exclusion should be recognised [along with time (history)]. Secondly, that merging aspects of social constructivist and political economic thought provides a more inclusive understanding of disability. An understanding of how disabled people have become marginalised and excluded within society cannot be understood without an appreciation of the socio-spatial processes that reproduce social relations. Social theorists are increasingly coming to recognise that life and society are not solely constituted in time and history but are also situated, contextualised and reproduced in space (see Giddens, 1991; Harvey, 1989; Jameson, 1991; Soja, 1989). With in this spatial turn, space is understood as not just a passive container of life, but also as an active constituent of social relations: space is not only given, 'an absolute container of static, though movable, objects and dynamic flows of behaviour' (Gleeson, 1996, p. 390), absolutely defined and understood with Euclidean geometry, space is also socially produced and constructed, dynamic and ambiguous, claimed and contested (see Wolch and Dear, 1989). It is recognised that urban and rural landscapes have been sculptured and shaped by people and attributed cultural significance. As an active 
constituent of social relations, space is socially produced to exclude disabled people in two main ways:

- spaces are currently organised to keep disabled people 'in their place';

- spaces are social texts that convey to disabled people that they are 'out of place'.

As separate approaches social constructivism and political economy are limited and limiting. Social constructivism posits that society's reaction to, and the experiences of, disability is mediated through culture as a social process. It rejects social determinist ideas, that the structures of capitalis $m$ dominate how disabled people are treated by society. Constructivists are interested in studying the social processes, the interactions of actors and institutions, that underpin the construction of disability. Political economists, whilst acknowledging the constructed nature of disability, suggest that disability is constructed to reproduce capitalist relations. They seek to expose the inherent injustices within present social relationships that they argue are the result of the economic bases of capitalism. They argue that all social relationships are constrained within regulating capitalist structures. These structures exist as a means of enforcing and reproducing wealth for a minority of the population through the exploitation of labour. Contemporary western society is thus characterised by a capitalist 'mode of production' as the means people employ to sustain themselves. Within this mode there are inherent contradictions that need to be exposed, so that unfair social relationships enshrined in the class system, and also expressed in the exclusion of disabled people, can be overthrown.

It is increasingly clear that the relationships between disability and society cannot be framed within either strict economic and political terms or purely socio-cultural processes, but must encompass a mixture of the two. In a mixed approach, disabled people are excluded not only because of capitalist mode of production, but also because of socially constructed modes of thought and expression enshrined in cultural representations and cultural myths. The neo-Marxist might claim that such representations and myths are a particular manifestation or expression of capital. Such claims can be rejected: all behaviour and action are not predicated upon capital concerns. For example, exclusionary processes within Northern Ireland between Nationalist and Unionists are predominantly predicated upon territory and power, not capital. Whilst it could be argued that the sociospatial nexus in Northern Ireland was a result of feudal capital relations, the current conflict has shifted in emphasis. Class, whilst important, is only one axis of oppression within society with disability, gender, race, sexuality, religious beliefs and nationality providing the context in which other power relations operate: there are multiple, interacting fields of power (Pile, 1997). Processes of oppression can arise out of the social mobilisation of groups of individuals with conflicting interests. The focus of attention should therefore shift from capital and class to power in its various manifestations.

Young's (1990) classification of oppression can be used to illustrate the variety of power relations and processes of exclusion in relation to disabled people. In the first instance, disabled people are rendered 'powerless'; power relationships between 
able-bodied and disabled people are maintained through political means. Disabled people are denied access to important decision-making positions within society. Secondly, disabled people are marginalised within society and social life: power relationships are maintained through social means. Disabled people are 'pushed' into poor housing, denied access to private and public transport, and are ostracised from 'mainstream' social activities such as visiting the pub or cinema through poor provision and weak statutory laws. Thirdly, disabled people are exploited with in the labour market: power relationships are maintained through material means. Disabled people are often excluded from labour market through discriminatory practices and poor levels of mobility. Where they do gain access it is usually in margin positions undertaking low-paid, low-skilled work often on a part-time basis. Such a situation works to deny disabled people prosperity and wealth, and their associated power. Fourthly, the maintenance of power can be achieved through violent means. People who do not hold the same values or live the same way as the dominant group are repressed through physical violence and imprisonment. The system of asylums and imprisonment have been one particular method used to confine and oppress disabled people. Lastly, power relationships are maintained through the use of ideology, through a form of cultural imperialism. The dominant group's cultural practices are promoted as the norm and the cultural practices of Others are portrayed as deviant. As such, disabled people are taught to 'know their place', to believe the logic of the oppression; that they are unworthy and deserve to be where they are on the social ladder, "ffatalistically" accepting their exploitation' (Freire, 1970 , p. 46). They are taught patterns of self-blame, self-shame and self-doubt (Wendell, 1989).

These forms of oppression are played out within space and are given context by space. Space is organised and written to perpetuate disablist practices. Society is socio-spatially organised to sustain hegemonic power within a nested set of social relationships at varying spatial scales. If we are to understand disability and the experiences of disabled people we must deconstruct the landscapes of power and exclusion, and the geographies of domination and resistance.

\section{The Disablist Organisation of Space}

Imrie (1996) contends that space is organised to perpetuate the dominance of 'able-bodied' people. Environments that exclude disabled people are rarely 'natural', they are produced through individual social interactions combined with State policy, building regulations, and architectural and planning practice (Imrie, 1996). Barriers to inclusion are clearly evident in the urban environment. Urban space is implicitly and explicitly designed in such a way as to render certain spaces 'no go' areas. For example, implicit or thoughtless designs include the use of steps with no ramp; cash machines being placed too high; places linked by inaccessible public transport. Such practices are enshrined in, and perpetuated by, the planning system. Current planning practice is underlain by modernist concerns for aesthetics and form over building use with environments and buildings designed as if all people are the same-abled-bodied (Matthews and Vujakovic, 1995). The current car-designed 
city is ill-suited to disabled people reliant on public and authority transport, with the changing retail geography (e.g. out-of-town centres) exasperating the problems of shopping access. Even when a space is designed for disabled access it is often misused with disabled toilets becoming stores and obstacles positioned so as to block accessible entrances (see Napolitano, 1995).

Imrie (1996) suggests that current urban planning is underscribed by a 'design apartheid' whereby planners, architects and building control officers are guilty of constructing spaces which 'lock' disabled people out; which prioritise the dominant values of the 'able-bodied' community. Here, the dominant underlying ethos is one that follows the State's line of integration or assimilation-to bring people back to 'normality'. As such, policy is aimed at trying to make disabled people more 'normal' rather than changing the system to accommodate disabled people for who they are. Furthermore, while the rhetoric alludes to independent living, the reality is a dependency upon community and welfare provision.

Some spaces are designed to deliberately segregate and 'protect' the public from disabled people and vice versa (e.g. special schools, asylums). Philo (1987, 1989) provides a detailed historical account of how space has been explicitly organised to separate people with mental impairments or people who are mentally ill from the rest of society. By shifting through back issues and analysing the articles and editorials contained within the Asylum fournal, a quasi-academic journal concerning mental health institutions and practice, he provides a detailed geo-historical account of asylums in nineteenth century Britain. Thinking at this time was dominated by a medico-moral discourse that promoted segregated institutions sited in tranquil, healthy and rural environments. These sites not only segregated 'patients' but were thought to offer suitable environments for treatment and recovery. The segregation of mentally impaired people continues today, usually accompanied by treatment aimed at making 'patients' more 'normal', or sedation or sterilisation to protect 'sane' people and themselves from self-harm.

People with physical and sensory impairments have also been encouraged and forced to live in different spatial spheres. Segregated schools are still common place for deaf, blind, physically and hidden impaired children, and segregated employment training and day-care units are not uncommon. Even within public spaces, disabled people are separated and marginalised to the peripheries. For example, where there are disabled accessible public toilets (and these are still uncommon) they are mostly separate from able-bodied toilets, asexual (both sexes share the same space), and usually locked, whereas the able-bodied can visit the toilet at any time, disabled people often have to search for the key (sometimes held in an inaccessible part of the building!). Theatres generally restrict wheelchair users to certain areas within the auditorium, usually towards the back or the side. Imrie (1996) argues that segregation, whilst promoted as ways to help assimilate disabled people in society through empowerment and independence, perpetuates disablism by labelling disabled people as different, as needing specialised and segregated facilities. Segregation thus propagates and reproduces the position and status of disabled people. As such, popular misconceptions concerning disabled people are reproduced.

Neo-Marxist thinkers, such as Hahn (1987), Oliver (1990) and Gleeson 
(1996), argue that the separation of disabled people from the rest of society is the direct result of the shift from feudal to industrial capital relations. Whereas in feudal times all members of the community had a role to play in sustaining life within the home (severely disabled people rarely lived to adulthood), with the onset of industrialisation and the regulation of individual and collective labour, disabled people were labelled as under- or non-productive. Unemployed disabled people, excluded from the workplace, provided no income and became family burdens. The poor house quickly became disabled 'asylums', predominantly occupied by children, the 'insane', the 'defective' and the 'infirm' (elderly). The advent of consumerism, rather than self-sufficiency, and associated advertising helped to place an emphasis upon health and the body beautiful, further stigmatising and perpetuating discrimination against disabled people (Hahn, 1987).

Accompanying industrialisation was the start of the Enlightenment period. In this period, medical sciences started to explore and chart human physiology. Eugenics used statistical measurements to categorise people with the express aim of normalising those who deviated away from the 'average' (Davis, 1995). A whole set of medical professions grew up to manage disabled people unable to earn a wage (Finkelstein, 1993). Segregated spaces provided the location for the process of normalisation to occur, whilst 'protecting' the general public from the abnormal. Segregation also meant that those 'beyond' normalisation were prevented from socialisation and reproduction serving to eliminate 'defectives' from future populations. Within a neo-Marxist frame of analysis the current shift towards deinstitutionalisation and care in the community can be seen, not as a way of improving the care and lives of those in need, but rather as a way to save the State capital. Whilst this movement does disrupt and fragment formal segregated spaces it is leading to a new set of informal segregated spaces amongst the gutters, sidewalks, hostels and bedsits of cities. Undoubtedly capital relations have structured disabled people's lives; however, it is contended that disablist practices are constituents of a wider set of socio-spatial power relations.

\section{Spatial Manifestations of Disablist Social Relationships}

In addition to disablist organisation of space, the organisation of social relations currently spatially isolate and marginalise disabled people, and their carers. A classic example of how society spatially disadvantages disabled people is the design and maintenance of public transport. Many disabled people are denied the freedom to travel where and when they like. Their spatial behaviour is restricted because they are unable to walk or drive themselves and public transport is either poorly designed or there is inadequate provision (e.g. infrequent or unreliable service). Often journeys have to be planned several days in advance, to allow time to book provision. For example, it is not possible for wheelchair users to travel on the London underground without pre-booking 24 hours in advance, and then travel is restricted to stations with a lift. Disabled people often have to travel circuitous routes and are denied the same spatial choices as 'able-bodied' people. Consequently, access to employment and social events can be denied. The spatial manifestations of inaccess- 
ible public transport reproduces unemployment and underemployment amongst disabled people, and restricts their social activities. This, in turn, restricts the ability to earn, and thus confines them to poor, cheap and inadequate housing and welfarist lifestyles. Similarly, holiday destinations are limited because of difficulties in getting there and finding somewhere that caters for specific needs.

In cases where welfare provision is an essential part of daily life, and institutionalisation has been rejected, social relationships currently place an emphasis on authority-provided care or family care with little or no support. Authority provided care usually consists of 'helpers' coming several times a week to help with household chores such as cooking and cleaning. Usually, visits are timetabled and set to a routine. Spatial behaviour is restricted to modes of travel provided by the authority, and is limited both in time and distance. Trips outside the home usually have to be timetabled carefully in advance. Where a family member is the main carer, inadequate and infrequent support can place an intolerable burden upon the carer, and severely strict their own and their disabled caree's spatial behaviour. Feminist analysis of the geographies of child-care has demonstrated that because of their role within the home, women's spatial behaviour is restricted and unrewarding in comparison to men's (see England, 1997). Milligan (1997), in a study of the geographies of caring within Glasgow, has drawn similar conclusions for carers. Carers are tethered to the site of caring, especially if they are the sole carer, with little time for social life. Spatial behaviour is usually restricted to walking distance of the site of care, or short car journeys to specific locations such as shops. In addition, provision of relief support by local authorities varies across districts because of priorities and patterns of spending. Where people live then effects the level and extent of carer support. If the carer, the partner with the most mobility, is restrained, then the disabled caree is even more spatially and socially isolated, often confined to the home and rare visits to day-care centres.

\section{The Disablist Writing of Space}

Good inclusive design will send positive messages to disabled people, messages which tell them: 'you are important'; 'we want you here'; and 'welcome'.... if the way that disabled people are expected to get into a building is round the back, past the bins and through the kitchens, what does that message communicate? How will it make a disabled person feel?' (Napolitano, 1995, p. 33.)

Who is felt to belong or not belong in a place has important implications for the shaping of social space (Sibley, 1995). We live and interact in spaces that are ascribed meaning and convey meaning. A city is not just a set of buildings, roads, parks and other infrastructure, a city is also a (cultural) text which we read and react to (Donald, 1992). Spatial structures and places within the landscape provide a set of cultural signifiers that tell us if we are 'out of place' (Cresswell, 1996). These can be explicit (e.g. murals identifying the political affiliations within Northern Ireland or graffiti marking out gangland territory in US cities) or implicit in nature (e.g. the 
type and appearance of housing). We read the symbolic meanings of landscape to indicate to us how to act. For example, we know that a church symbolises reverence, a library to be silent. Through social and cultural practices we are taught how to read and react to the cultural landscape (see Duncan \& Ley, 1993). In doing so, we are indoctrinated into perpetuating and reproducing the meanings and messages that spaces convey. This, in turn, leads to distinct spatialities such as the concentration of certain minority groups within areas of the city (e.g. black ghettos and gay enclaves). In effect, certain spaces are socialised by certain homogeneous groups who regulate and exclude 'unwelcome' visitors. Social spaces, as found in any city, are contested through processes of domination and resistance. Social spaces can be identified that are constructed through identity politics relating to disability, gender, race, ethnicity, class and sexuality. Social relationships are mediated through a variety of socio-spatial processes and space is produced in such a way as to maintain current power relations.

Overt or implicit discrimination through cultural practices work to keep disabled people 'in their place'. At an individual level this is expressed through indifference and ignorance. As Cresswell (1996) illustrates with phrases such as 'know your place' and 'a place for everything and everything in its place', some things and some people are determined to belong in one place and not in another, depending on their relationship to Others. When people are out-of-place it is a cause for concern because of perceived threat to power relations. Many comic films feed on this person out-of-place situation (e.g. Trading Places where a down-and-out and a city trader swap lifestyles). One way to ensure people know their place is through the creation of cultural norms and identifiable social spaces; for people to be indoctrinated into 'knowing their place' through cultural practice and taught how to read cultural landscapes. For example, the majority of us experience guilt or apprehension when we know we are somewhere we should not be, like hiding in your parent's bedroom or sneaking into the boss's office. Moreover, most of us feel uncomfortable or threatened when someone from a different level with in the social hierarchy strays uninvited into our space, such as when a person with a mental illness moves into our neighbourhood. Such anxieties have been well documented in relation to community care (see Dear \& Wolch, 1987; Currie et al., 1987). Here, we are reacting to place-inscribed ideologies that guide our thinking and behaviour. The writing of disablist space can also be explicit. For example, Imrie (1996) reports that some cities in the USA still have signs telling disabled people not to live in those areas. For example, a sign in Chicago in the 1960 s read:

No person who is diseased, maimed, mutilated or in any way deformed so as to be unsightly or disgusting object or improper person to be allowed in or on the public ways or other public places in this city shall therein or thereupon expose himself to public view. (Imrie, 1996, p. 15.)

Cresswell (1996) describes how places reproduce the meanings associated with them in natural, self-evident and common-sense ways-'we are silent in a library because we believe it is appropriate to be silent in libraries, and by being silent in libraries we contribute to the continuation of silence' (p. 16). As such, these cultural norms are 
situated and contextualised within a historical legacy so that society is reproduced and perpetuated (although there is fluidity so that norms do gradually change and evolve). As such, exclusionary practices such as inaccessible environments are unconsciously reproduced as something which is natural, which is commonsense. $\mathrm{He}$ suggests that the majority of the population are generally unaware of the processes of exclusion; they are an unconscious part of everyday life. In other words, able-bodied conceptions of the world are unconsciously accepted with disabled perspectives little considered. As a result, the socio-spatial system is reproduced with little challenge. Cresswell (using Bourdieu's term) refers to this as doxa (dominant ideology), an unconscious acceptance, or the taken-for-granted, way of things (even by the oppressed group). Social ordering is thus legitimised through a 'natural' or 'commonsense' classification where exclusionary practices are understood as acceptable. People come to 'know their place'. Freire (1970) suggests that this dominant ideology is largely invisible to the oppressed group because their perceptions of themselves are submerged in the reality of oppression. Oppression is not only common-sense it is 'domesticating'. Socio-spatial relations are thus ordered and maintained through the dominant ideology.

The ideological messages to disabled people that are inscribed in space through the use of segregationist planning and inaccessible environments are clear-'you are out of place', 'you are different'. As a result, forms of oppression and their reproduction within ideologies leads to distinct spatialities with the creation of landscapes of exclusion, the boundaries of which are reinforced through a combination of the popularising of cultural representations and the creation of myths. Cultural representations are employed by the dominant society in order to portray Other. Commonly, analogies to things considered to be 'bad' are used. For example, Others are often portrayed as being impure, defiled, contaminated or dirty. This is achieved through processes which seek to de-humanise the subordinate group (see Jackson, 1989; Pratt \& Hanson, 1994). For example, Nazi Germany used popularised cultural representations to argue that the Jews and Gypsies, along with both physically and mentally impaired people, were dirty, animals, contaminated, physically different and imperfect, thus threatening the purity and stability of the Aryan race, to motivate widespread persecution of these groups (Jackson, 1989). Feeding into and from cultural representations are cultural myths. Myths take the form of malicious gossip which feeds into stereotypical representations.

Disabled people have long been labelled as deviant, as Other. Their position within society has been greatly affected by the production and perpetuation of cultural representations and cultural myths. These have been fed in the main by their 'deviancy' from the 'normal' and their supposed inferiority and danger. Disabled people are 'freaks of nature' deemed to be abnormal, unproductive, unattractive, anti-social and tainted by disease/ill-health. They are 'non-human', 'burdens of charity' and 'diseased organisms' (Cocks \& Cockram, 1995), labelled with monster images and their ability to carry out the most mundane of tasks questioned (Hahn, 1988). Disabled people, regardless of impairment, are often labelled 'retarded', unable to cope on their own. They are the charity cases, reliant on hand-outs and hand-ups; the hangers-on (from death), ungodly and unsightly. As 
Hevey (1993) discusses media images reinforce these notions of disabled people as ignorant, child-like hyperdependent and flawed. Segregationist practices further heighten fear and suspicion. When disabled people do live independently they are thought of as the 'plucky hero/heroine', defying their impairment and natural selection. When they marry and have children, the able-bodied partner or the child is pitied, and the disabled partner/parent often condemned for transgressive and irresponsible behaviour (see Shakespeare et al., 1996). Such is the stigma of the disability label that many disabled people deny or seek to hide their impairment. Within these representations and myths disability is constructed as a medical and individual problem-disabled people are just the tragic victims of nature (birth) or fate (accident, disease, etc.). As such, society is absolved of blame and guilt for disablist practices.

Representations of and myths surrounding disability are sociospatial constructions. They are specific methods for keeping disabled people 'in their place'. Conceptions of disability are rooted in specific sociospatial and temporal structures. These structures form, sustain and perpetuate the popular stereotypes which underlie many exclusionary practices and are enshrined within the maintenance of the dominant ideology. Evidence has shown that different societies do react differently to impairment. Winzer (1993), for example, provides a detailed account of disability from pre-Christian to the eighteenth century. Within these civilis ations disability was conceptualised as a tragic flaw measured against some ideal and while disabled people were victimised they were still visible members of the community (Finkelstein, 1993). It was only after the mid-nineteenth century that the concept of normality underlay conceptions of disability and disabled people became less visible in the social landscape (Davis, 1995). It has only been in the last few decades that disability has been seen as a social construct and not just as medical conditions.

\section{Space and Resisting Disablist Practices}

To change life ... we must first change space. (Lefebrve, 1974, p. 190.)

To boldly go where others have been before. (Direct Action Network slogan.)

In recent years, to accompany the growing recognition of the 'geographies of domination' have been studies of how people deal with, and resist, oppressive practices (see Pile \& Keith, 1997). Resistance is the opposition of power: the oppressed fighting back against the injustices imposed by their oppressors. Resistance like domination has a spatiality, geographies in which it is mapped and which it seeks to change. Any understanding of resistance must acknowledge the sociospatial context and location of resistive acts examining historical and geographical situatedness of oppression (Harvey, 1993). The spatialities of resistance whilst similar, and inextricably linked to those of domination, do not however mirror them (Pile, 1997). The relationships between the two are complex and tangled, operating at different levels and spatial scales. For example, local acts of resistance are not always an expression against specific, local processes of domination, but may be 
reactions against wider, national oppressive policies. The reasons why different people join in an act of resistance are not unified and they may be acting against related, but different forms of oppression. Similarly, resistance against different forms of oppression (disability, gender, race, sexuality) can become confused, related and shifted. An analysis of 'geographies of resistance' has so far little considered disablist practices.

Disabled people have always resisted the dominant ideology, but mainly in ways that were defiant and individual based. Actions range from living the lives they want, getting an education and a job, to having children, not hiding their 'deformities', rejecting 'normalising' treatment, battling against stereotypes and prejudice, and seeking to get 'able-bodied' people to accept them as they are (see Asch \& Fine, 1988). In recent decades, disabled people and their allies have started to explore more collective and confrontational ways to turn sites of oppression and discrimination into spaces of resistance. From the early 1970s, a disabled equal opportunities movement began to grow in Britain. Disabled activists started to take over organisations that proclaimed to represent them or set up their own organisations such as UPIAS (Union of Physically Impaired Against Segregation; see Leach, 1995). In more recent years, actions by advocacy groups, such as Disabled People's Direct Action Network (DAN) have used direct protest to highlight disability issues. ${ }^{1}$

To understand these resistive acts and the process of resistance Routledge (1997, p. 71) contends that 'it is necessary to understand how such sites are created, claimed, defended, and used (strategically and tactically)'. In other words, understanding resistance is more than rationalising acts in time and historical context, but also in space-why the resistive act was carried out where it was. For example, in 1995 DAN protested outside the Houses of Parliament about the then proposed Disability Discrimination Act (DDA). This site was chosen for two primary reasons. First, the Members attention would be drawn to disablist practices. Secondly, the event was guaranteed to draw much needed media attention to the inadequacies of the proposed DDA. By chaining themselves to entrance of buses wheelchair bound members of DAN explicitly demonstrated public transport's inaccessible nature whilst highlighting the sub-standard and inadequate provisions of the planned legislature. DANs actions were timed to coincide with parliamentary debates concerning the Act. The protest was carefully stage-managed, in space and time, to try and make a maximum impact. In 1996, DAN extended its political campaigning to protests within key government marginal seats, and especially those whose Member's of Parliament had failed to address disability issues, in the lead-up to the general election. By focusing upon particular political spaces as the sites of resistance DAN aimed to change the political map by aiding the downfall of the disablist, governing political party. Other actions in 1996 focused upon particular cities, for example Nottingham, home of the then Chancellor of the Exchequer, and which has done little to improve disabled access. DAN protesters in this instance chained themselves to buses and brought much of the city centre to a standstill on two consecutive days. Sites of public transport are particular spaces of resistance that DAN has aimed to develop with bus and train stations particular targets. Projects 
such as centres of independent living similarly seek to grasp control of a specific space as a site of resistance against institutionalised care.

\section{Conclusions}

In this paper it has been argued that disability is socio-spatially constructed. An understanding of space, as well as time and history, is necessary for a comprehension of disablist oppression and disabled resistance. Space is instrumental in the reproduction, sustenance and resistance of disablist practices. The organisation and writing of space are expressions of disablist power relations within society. The spatialities of disability are configured to convince disabled people that they are 'out of place' and to keep them 'in their place'. Furthermore, social relationships currently spatially isolate and marginalise disabled people. It has been contended that disability is best understood through an approach that combines a spatialised political economy with social constructivism. This approach recognises the centrality of power; the multifaceted ways and reasons for the socio-spatial exclusion of disabled people; and the complexity of strategies of domination and resistance. Disability is not only a function of capital relations but is also tempered by stigma and fear of the unknown. Class and capital are only one facet of the contemporary cultural politics which regulates and reproduces disablist social relations.

At present, there is a lacuna of studies of the spatialities of disability. Geographers, those who might be charged with studying the spatial, have only recently started to identify and examine the socio-spatial processes of disabled exclusion, oppression and resistance. ${ }^{2}$ As such, there is the need for studies which seek to examine and expose the socio-spatial processes which underlie disablist practices and disabled resistances in contemporary western society. This paper has sought to highlight some of the issues that need further exploration.

\section{Acknowledgements}

I would like to thank Brendan Gleeson, Mike Dorn, Rob Wilton and the two anonymous referees for their constructive comments of an earlier draft of this paper.

\section{NOTES}

[1] DAN's web pages can be found at: http://www.disabilitynet.co.uk/groups/dan/.

[2] For a bibliography of disability research with a geographical flavour see the Disability and Geography Resource Site: http://web.qub.ac.uk/geosci/research/geography/disbib/ disgeogl.html.

\section{REFERENCES}

Asch, A. \& Fine, M. (1988) Nurturance, sexuality, and women with disabilities: The example of women and literature in: M. FINE \& A. AsCH (Eds) Women with Disabilities, pp. 13-29 (Philadelphia, Rutgers University Press).

Cocks, E. \& Cockram, J. (1995) The participatory research paradigm and intellectual disability, Mental Handicap Research, 8, pp. 25-37. 
Cresswell, T. (1996) In Place/Out of Place: geography, ideology and transgression (London, UCL Press).

Currie, R.F. Trute, B. Teft, B. \& Segall, A. (1989) Maybe on my street: the politics of community placement of the mentally disabled, Urban Affairs Quarterly, 25, pp. $298-321$.

Davis, L. (1995) Disability, Deafness, and the Body (London, Verso).

DeAR, M. \& Wolch, J. (1987) Landscapes of Despair: from deinstitutionalisation to homelessness (Oxford, Polity Press).

Donald, J. (1992) Metropolis: the city as text, in: R. Bocock \& K. THOmpson (Eds) Social and Cultural Forms of Modernity, pp. 417-470 (Cambridge, Polity Press).

Duncan, J. \& LEY, D. (Eds) (1993) Place/Culture/Representation (London, Routledge).

ENGLAND, K. (Ed.) (1997) Who Will Mind the Baby: geographies of child care and working mothers (London, Routledge).

Finkelstein, V. (1993) The commonality of disability, in: J. Swain, V. Finkelstein, S. FrenCH \& M. Oliver (Eds) Disabling barriers-enabling environments, pp. 9-16 (London, Sage).

Freire, P. (1970) Pedagogy of the Oppressed (London, Penguin).

GIDDEns, A. (1991) Modernity and Self-identity: self and security in the late modern age (Cambridge, Polity Press).

Gleeson, B.J. (1996) A geography for disabled people? Transactions of the Institute of British Geographers, 21, pp. 387-396.

Hahn, H. (1987) Advertising the acceptably employable image: disability and capitalism, Policy Studies fournal, 15, pp. 551-570.

HAHN, H. (1988) The politics of physical differences: disability and discrimination, fournal of Social Issues, 44, pp. 39-47.

Hanson, S. \& Pratt, G. (1995) Gender, Work and Space (London, Routledge).

Harvey, D. (1989) The Condition of Postmodernity (Oxford, Basil Blackwell).

HARveY, D. (1993) Class relations, social justice and the politics of difference, in: M. KEITH \& S. PILE (Eds) Place and the Politics of Identity (London, Routledge).

Hevey, D. (1993) The tragedy principle: strategies for change in the representation of disabled people, in: J. Swain, V. Finkelstein, S. French \& M. Oliver (Eds) Disabling Barriers-enabling environments, pp. 116-121 (London, Sage).

IMRIE, R. (1996) Disability and the City: international perspectives (London, Paul Chapman Publishing).

JACkson, P. (1989) Maps of Meaning (London, Routledge).

Jameson, F. (1991) Postmodernism, or the Cultural Logic of Late Capitalism (London, Verso).

LEACH, B. (1995) Disabled people and the equal opportunities movement, in: G. HALES (Ed.) Beyond Disability: towards an enabling environment, pp. 88-95 (London, Sage).

Lefebvre, H. (1974) The Production of Space (Oxford, Basil Blackwell).

Matthews, M.H. \& Vujakovic, P. (1995) Private worlds and public places: mapping the environmental values of wheelchair users, Environment and Planning A, 27, pp. 1069-1083.

Milligan, C. (1997) 'Bearing the Burden': a geography of caring, paper presented at ENRGHI 97, 1-2 July, Queen Mary and Westfield College, University of London.

Napolitano, S. (1995) Mobility impairment, in: G. Hales (Ed.) Beyond Disability: towards an enabling environment, pp. 30-35 (London, Sage).

Oliver, M. (1990) The Politics of Disablement (Basingstoke, Macmillan).

Oliver, M. (1996) Understanding Disability: from theory to practice (Basingstoke, Macmillan).

PHILO, C. (1987) 'Fit localities for an asylum': the historical geography of the 'mad-business' in England viewed through the pages of the Asylum Journal, fournal of Historical Geography, 13, pp. 398-415.

Philo, C. (1989) 'Enough to drive one mad': the organisation of space in 19th century lunatic asylums, in: J. WOLCH \& M. DEAR (Eds) The Power of Geography: how territory shapes social life, pp. 258-290 (London, Unwin Hyman).

PILE, S. (1997) Introduction: Opposition, political identities and spaces of resistance, in: S. PILE \& M. KeITH (Eds) Geographies of Resistance, pp. 1-32 (London, Routledge). 
Pile, S. \& Keith, M. (Eds) (1997) Geographies of Resistance (London, Routledge).

Pratt, G. \& HAnson, S. (1994) Geography and the construction of difference, Gender, Place and Culture, 1, pp. 5-29.

Routledge, P. (1997) A spatiality of resistances: theory and practice in Nepal's revolution of 1990, in: S. PILE \& M. KEITH (Eds) Geographies of Resistance, pp. 68-86 (London, Routledge).

Shakespeare, T., Gillespe-Sells, K. \& Davies, D. (1996) The Sexual Politics of Disability: untold desires (London, Casell).

Shurmer-Smith, P. \& Hannam, K. (1994) Worlds of Desire, Realms of Power (London, Edward Arnold).

Sibley, D. (1995) Geographies of Exclusion: society and difference in the west (London, Routledge). SoJA, E. (1989) Postmodern Geographies (London, Verso).

Wendell, S. (1989) Towards a feminist theory of disability, Hupatia, 4, pp. 104-122.

WINZER, M.A. (1993) The History of Special Education: from isolation to integration (Washington, DC, Gallaudet University Press).

Wolch, J. \& DEAR, M. (Eds) (1989) The Power of Geography: how territory shapes social life (London, Unwin Hyman).

Young, I.M. (1990) Fustice and the Politics of Difference (Princeton, Princeton University Press). 